\title{
COMPARISON STUDY OF BRACING CONFIGURATION WITH SHEAR LINK IN ECCENTRICALLY BRACED FRAME STEEL STRUCTURE
}

\author{
Jusuf Wilson Meynerd Rafael ${ }^{1}$, Alva Yuventus Lukas ${ }^{2}$ \\ ${ }^{1}$ Civil Engineering Department, State Polytechnic of Kupang, Kupang, 85228, Indonesia \\ ${ }^{2}$ Civil Engineering Department, State Polytechnic of Kupang, Kupang, 85228, Indonesia \\ E-mail: wilsonrafael.jtspnk@gmail.com
}

\begin{abstract}
The EBF structural system is identified by the use of bracing and link beams as components that work to receive lateral seismic loads. The position of the link beam makes the EBF system have several choices of bracing configuration; D-Braces, Split K-Braces, V-Braces, Split K \& Inverted Split K-Braces, Inverted Y-Braces. Structural analysis was carried out on a 10-story building model for the EBF system with different type of bracing configurations using the ETABS software. All models analyzed according to Indonesian Code (SNI 1729:2015 and SNI 1726:2019) to obtain the structural element. Seismic analysis uses the response spectrum analysis method to obtain the structural response parameters in the EBF system. Result of the analysis for all of bracing configuration are shown that Split K-Braces model has the best response parameters when compared to the MRF system. The lowest value for the parameter is owned by Inverted Y-Braces, although overall it is still larger than the MRF system. The bracing configuration greatly affects the response of EBF system due to the behavior that occurs in the link beam, therefore the selection for type of bracing configuration is also important in the EBF system structure design.
\end{abstract}

Keywords: bracing configuration; shear link, eccentrically braced frame; steel structure.

\section{Introduction}

\subsection{Background}

Steel material is still the choice as a structural material for seismic-prone areas, due to its high strength, elastic properties of steel contribute to better ductility and energy dissipation than concrete. In relation to seismic problems, there are several seismic resistant steel structure systems that can be applied to buildings, there are Moment Resisting Frame (MRF), Concentrically Braced Frame CBF), Eccentrically Braced Frame (EBF), Buckling Restrained Braced Frame (BRBF) and Special Plate Shear Walls (SPSW).

The Eccentrically Braced Frame (EBF) structural system is a combination of the Moment Resisting Frame (MRF) and Concentrically Braced Frame (CBF) structural systems. This is due to the limited inelastic behavior occuring in the beam link, while the other elements of the stucture remains elastic during the seismic load. Therefore, the EBF structural system can provide high ductility such as MRF system and can also provide high elastic stiffness such as CBF system [1-4].

Some possible types of bracing configurations for the EBF system are shown in Figure 1; (a) DBraces, (b) Split K-Braces, (c) V-Braces, (d) Split K \& Inverted Split K-Braces, (e) ) Inverted YBraces [5]. The yielding mechanism for every type of bracing configuration is very dependent on the position of the links beam (Figure 2) so that the resulting response value is different from each type of bracing. The links beam in EBF behaves as a short beam with shear forces acting in opposite 
directions at both ends so that the resulting moments at both ends of the beam have the same magnitude and direction. During the seismic load, the links beam will undergo inelastic rotation while other components of the EBF remain elastic, and finally the links beam becomes active and start yielding [6].

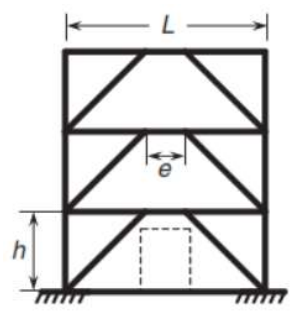

(a)

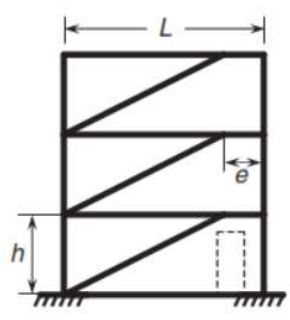

(b)

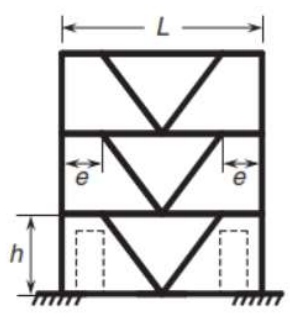

(c)

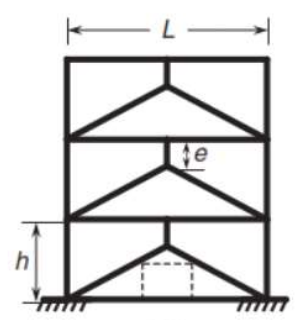

(d)

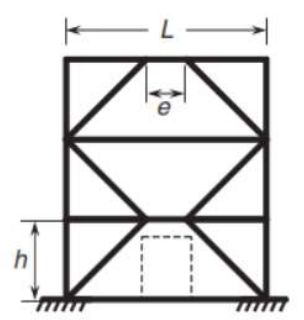

(e)

Figure 1. Typcal EBF configuration.

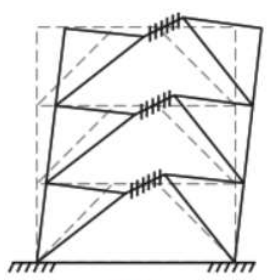

(a)

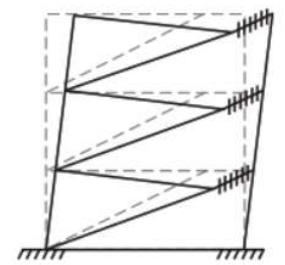

(b)

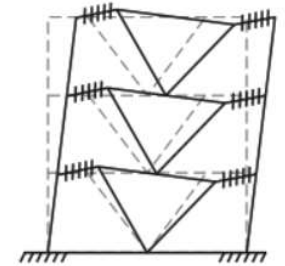

(c)

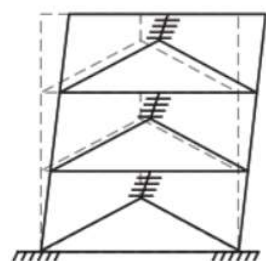

(d)

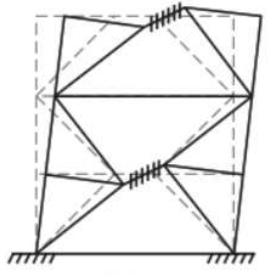

(e)

Figure 2. Yield mechanism of EBF.

The link beams in the EBF system are divided into three categories, there are short link (shear link), intermediate link (shear-flexural link) and long link (flexural link) which are determined from the normalization of the link length with the ratio between the plastic moment capacity (Mp) and the plastic shear capacity $(\mathrm{Vp})$. The classification of these link is shown in Figure 3 [7,8]. The experimental study of beam link elements conducted by Musmar [9] shows that the EBF system with shear yielding (short link) is more stable and exhibits more ductility than the flexural yielding (long link). This is due to the constant internal shear forces along the link and the yielding of the web that occurs along the web plane of the link. The numerical analysis carried out by Hashemi [10] of the EBF frame with the long link criteria indicates that yielding on the link beam is due to bending forces. The energy absorption on the flange is less than the shear link condition due to premature buckling 
on the flange of the link beam. To reduce this, the placement of the web stiffeners on the link beam can be controlled, although it is not very efficient because of the influence of torque.

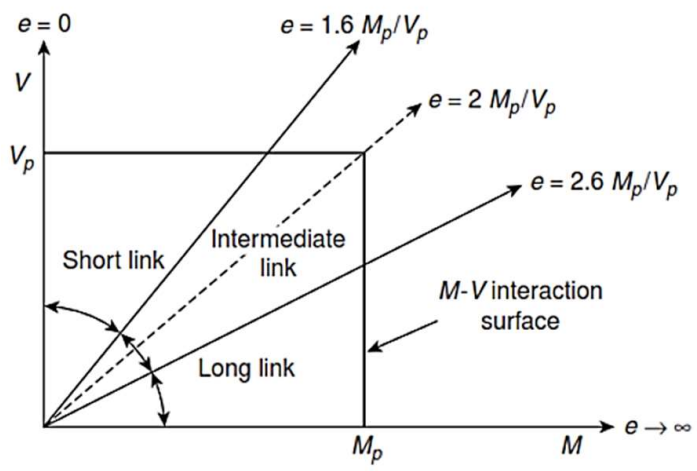

Figure 3. Classification of links.

The use of short links is always recommended in EBF structures because it shows better ductility, stiffness and strength than other link types [11]. The position of the link beam placement as a result of the bracing configuration on EBF systems make the final value of the structural response is different between each other. Therefore, in this article focus to analysis the various types of bracing configuration in EBF system with short link under lateral seismic loads to obtain the structural response. The MRF system is used as a comparison of how much influence for the bracing configuration.

\subsection{Problems}

The main problem to be discussed in this arcticle is how much difference in the structural response under the seismic loads for building structures using the EBF system in various types of bracing configurations with the MRF system as a comparison model.

\subsection{Scope}

The scope of this article is limited as follows;

1. The structure of the building being reviewed is a 10-story steel frame structure that functions as an office.

2. The structure layout of the building is symmetrical with each outer side part of the center portal given bracing configuration on the EBF system.

3. Beam and column joints are considered rigid and bracing joints in columns and beams are considered non-rigid.

4. The link beam are reviewed for short links only.

5. Dynamic seismic analysis uses response spectrum analysis in accordance with Indonesian Code (SNI 1726: 2019).

6. The location of the building structure is planned to be located in Kupang City with moderate soil conditions.

7. The structural response parameters reviewed for comparison are the fundamental period of structure, lateral deformation, drift and base shear forces.

\subsection{Aims}

The objectives achieved from this article are;

1. Calculate the fundamental period of structure, lateral deformation, drift and base shear force in various types of bracing configuraton for EBF system.

2. Comparing the structural responses generated by each type of bracing configuration in EBF system. 
3. Knowing how much influence the changes in the MRF system to be EBF system with bracing configurations.

\section{Methods}

\subsection{Analysis Process}

The analysis of the EBF model using ETABS software with 3-dimensional frame structure modeling. The material used for the structure is steel. To design each elements of steel structures is used linear elastic structure design method with seismic loading is static equivalent analysis. Furthermore, with the design results of the cross-sectional elements, dynamic response spectrum analysis is carried out to obtain the parameters of the fundamental period of structure, lateral deformation, drift and base shear produced by each EBF structural model.

\subsection{Data of Structure}

The building being reviewed is a 10-story steel structure building with the EBF system as a lateral seismic resistance structure. The steel material used is planned to have the quality of BJ41 steel $(\mathrm{Fy}=250 \mathrm{Mpa}, \mathrm{Fu}=410 \mathrm{MPa}, \mathrm{E}=200,000 \mathrm{MPa})$. The distance between the spans in the Xaxis and $\mathrm{Y}$-axis directions is $8 \mathrm{~m}$ with the number of spans for each direction is 3 spans. The total height of the building is $40 \mathrm{~m}$ with height of each story is $4 \mathrm{~m}$ with a typical layout plan as shown in Figure 4 . The dimensions of columns, main beams, secondary beams, and bracing are shown in Table 1. For link beams use the same dimensions with the main beam.

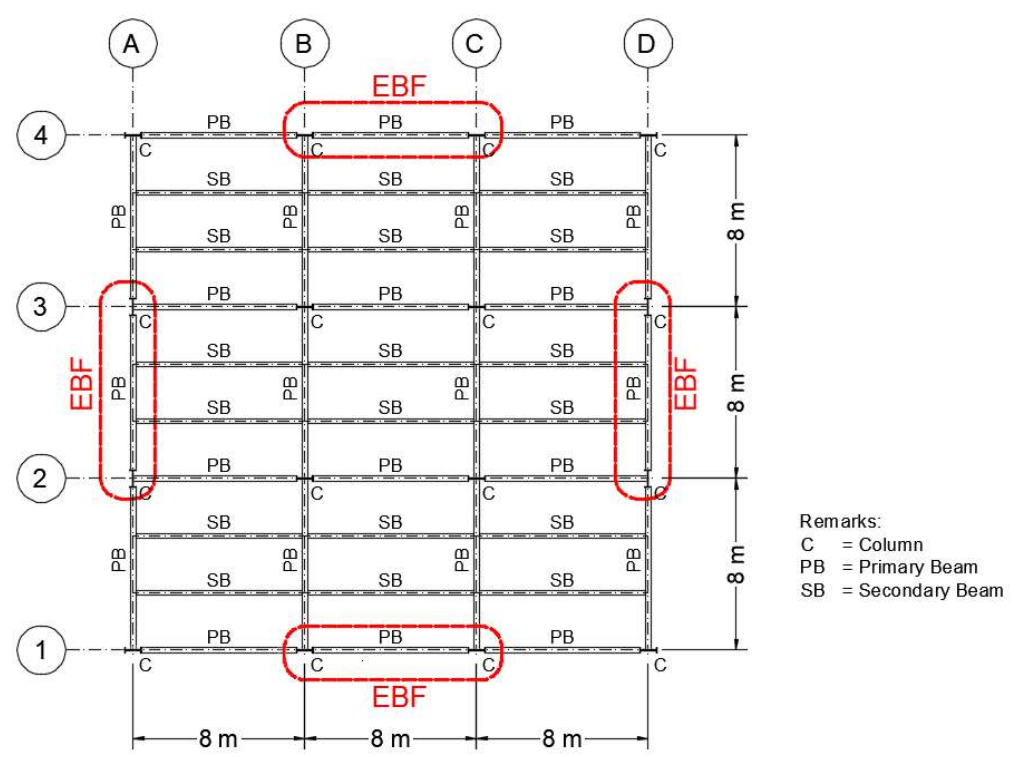

Figure 4. Story layout and position for EBF.

Table 1. Element profil for structural model

\begin{tabular}{ccccc}
\hline Story & $\begin{array}{c}\text { Column } \\
(\mathrm{KC})\end{array}$ & $\begin{array}{c}\text { Primary Beam } \\
(\mathrm{WF})\end{array}$ & $\begin{array}{c}\text { Secondary Beam } \\
(\mathrm{WF})\end{array}$ & $\begin{array}{c}\text { Bracing } \\
(\mathrm{WF})\end{array}$ \\
\hline $8-10$ & $588 \times 300 \times 12 \times 20$ & $434 \times 299 \times 10 \times 15$ & $400 \times 200 \times 13 \times 8$ & $300 \times 300 \times 15 \times 15$ \\
$5-7$ & $700 \times 300 \times 13 \times 24$ & $488 \times 300 \times 11 \times 18$ & $400 \times 200 \times 13 \times 8$ & $300 \times 300 \times 15 \times 15$ \\
$1-4$ & $800 \times 300 \times 14 \times 26$ & $588 \times 300 \times 12 \times 20$ & $400 \times 200 \times 13 \times 8$ & $300 \times 300 \times 15 \times 15$ \\
\hline
\end{tabular}


The type of link beam used in all EBF models is a short link which is determined from the plastic moment capacity $\left(\mathrm{M}_{\mathrm{p}}\right)$ and the plastic shear capacity $\left(\mathrm{V}_{\mathrm{p}}\right)$ of equations (1) and (2). Furthermore, from the $\mathrm{M}_{\mathrm{p}}$ and $\mathrm{V}_{\mathrm{p}}$ values obtained, the short link length is determined using equation (3) or as in Figure 3. The results of the calculation of the link beam length (e) are selected by $1 \mathrm{~m}$ as the length of the link beam used for the entire EBF model.

$$
\begin{aligned}
& M_{p}=Z_{x} f_{y} \\
& V_{p}=0.6 f_{y}\left(d-2 t_{f}\right) t_{w} \\
& e \leq 1.6 \times \frac{M_{p}}{V_{p}}
\end{aligned}
$$

with

$\mathrm{Z}_{\mathrm{x}}=$ plastic modulus of the section

$\mathrm{F}_{\mathrm{y}}=$ minimum yield stress

$\mathrm{d}=$ height of the section

$t_{\mathrm{f}}=$ flange thickness of the section

$\mathrm{t}_{\mathrm{w}}=$ web thickness of the section

Table 2. Length of link beam for EBF

\begin{tabular}{ccccc}
\hline Story & $\begin{array}{c}\mathrm{M}_{\mathrm{p}} \\
(\mathrm{N} . \mathrm{mm})\end{array}$ & $\begin{array}{c}\mathrm{V}_{\mathrm{p}} \\
(\mathrm{N})\end{array}$ & $\begin{array}{c}1.6 \mathrm{M}_{\mathrm{p}} / \mathrm{V}_{\mathrm{p}} \\
(\mathrm{MM})\end{array}$ & $\begin{array}{c}\text { Used } \\
(\mathrm{mm})\end{array}$ \\
\hline $8-10$ & $57,1813,750$ & 606,000 & $1,509.74$ & 1000 \\
$5-7$ & $774,959,000$ & 745,800 & $1,662.56$ & 1000 \\
$1-4$ & $1,077,228,000$ & 986,400 & $1,747.33$ & 1000 \\
\hline
\end{tabular}

\subsection{Variable Design}

Modeling of the 3-dimensional building structure is using ETABS software for 6 (six) structural models, there are 1 (one) MRF model and 5 (five) EBF models which represent the type of bracing configuration as shown in Figure 5. The references for structural design based on the requirements of Indonesian Code; SNI 1729:2015 [12] and SNI 1726:2019 [13].

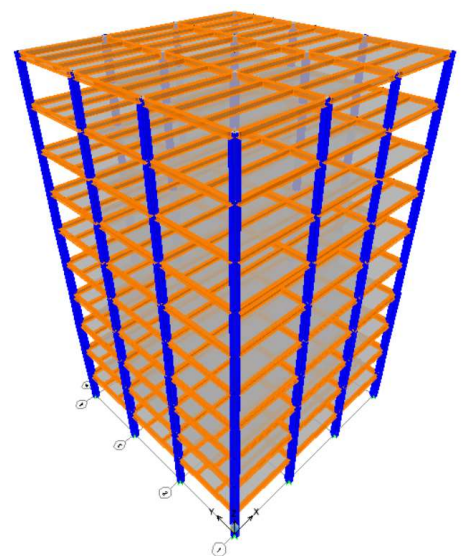

(a) MRF

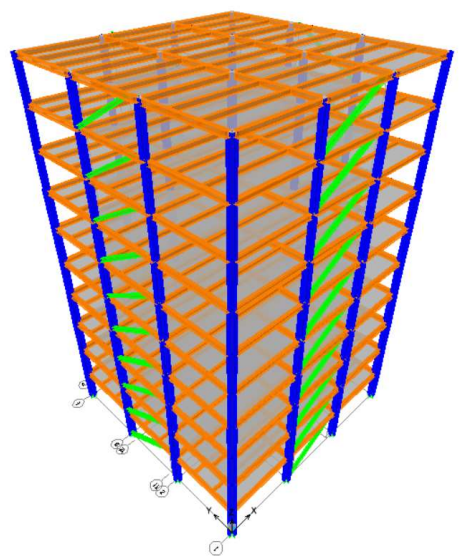

(b) EBF-01

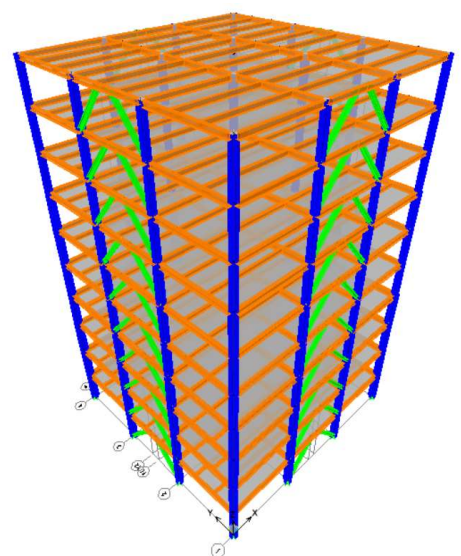

(c) EBF-02

Figure 5. 3D structure modeling for MRF dan EBF with bracing configuration in ETABS (part-1) 


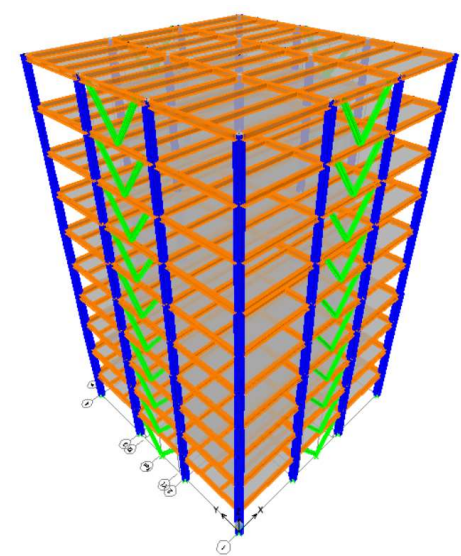

(d) EBF-03

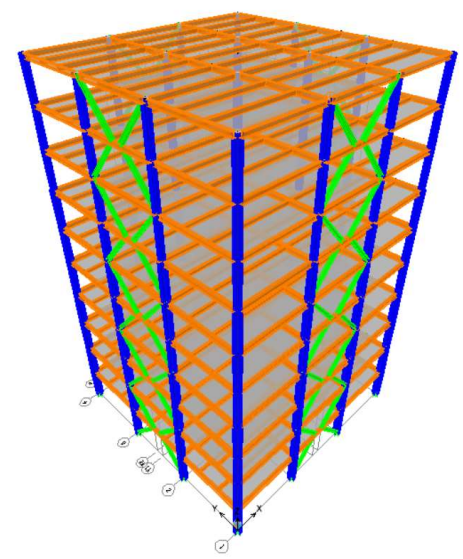

(e) EBF-04

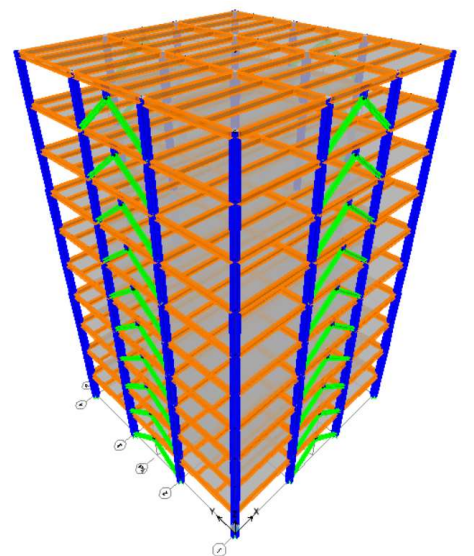

(f) EBF-05

Figure 5. 3D structure modeling for MRF dan EBF with bracing configuration in ETABS (part-2)

\section{Result and Discussion}

\subsection{Fundamental Period}

The fundamental period of structure $\left(T_{c}\right)$ of the output by ETABS shown in Table 3 shows the difference for each structural model. The MRF model have a greater fundamental period of structure than all of EBF models, which is 2.363 seconds, which is greater than the maximum limit for the approach fundamental period $\left(\mathrm{T}_{\mathrm{a} \text { max }}\right)$. For the EBF-05 model, although the value of the fundamental period of structure is still lower than the MRF model, it still exceeds the maximum limit of the requirements according to SNI 1726:2019 Section 7.9.1.4.1 [12]. Therefore, for MRF model and EBF-05 model is using value of T $=\mathrm{C}_{\mathrm{u}} \cdot \mathrm{T}_{\mathrm{a}}$. The Model EBF-01 to model EBF-04 has the fundamental period of structure is between limits of $T_{a}$ maximum and $T_{a}$ minimum, so the value of $T=T_{c}$.

Table 3. Period of structures

\begin{tabular}{|c|c|c|c|c|c|c|}
\hline \multirow{2}{*}{ Model } & \multirow{2}{*}{$\begin{array}{c}\text { Period of } \\
\text { Structure } \\
\mathrm{T}_{\mathrm{c}} \\
\text { (second) }\end{array}$} & \multicolumn{2}{|c|}{$\begin{array}{c}\text { Approach Fundamental } \\
\text { Period } \\
\end{array}$} & \multirow{2}{*}{ Control } & \multirow{2}{*}{ Used } & \multirow{2}{*}{$\begin{array}{l}\text { T final } \\
\text { (second) }\end{array}$} \\
\hline & & $\begin{array}{c}\mathrm{T}_{\mathrm{a} \text { min }} \\
\text { (second) }\end{array}$ & $\begin{array}{c}\mathrm{T}_{\mathrm{a} \max } \\
\text { (second) }\end{array}$ & & & \\
\hline MRF & 2.363 & 1.385 & 1.939 & $\mathrm{Tc}>\mathrm{Cu} . \mathrm{Ta}$ & $\mathrm{T}=\mathrm{Cu} \cdot \mathrm{Ta}$ & 1.939 \\
\hline EBF-01 & 1.583 & 1.163 & 1.628 & $\mathrm{Ta}<\mathrm{Tc}<\mathrm{Cu} . \mathrm{Ta}$ & $\mathrm{T}=\mathrm{Tc}$ & 1.583 \\
\hline EBF-02 & 1.471 & 1.163 & 1.628 & $\mathrm{Ta}<\mathrm{Tc}<\mathrm{Cu} . \mathrm{Ta}$ & $\mathrm{T}=\mathrm{Tc}$ & 1.471 \\
\hline EBF-03 & 1.565 & 1.163 & 1.628 & $\mathrm{Ta}<\mathrm{Tc}<\mathrm{Cu} . \mathrm{Ta}$ & $\mathrm{T}=\mathrm{Tc}$ & 1.565 \\
\hline EBF-04 & 1.556 & 1.163 & 1.628 & $\mathrm{Ta}<\mathrm{Tc}<\mathrm{Cu} . \mathrm{Ta}$ & $\mathrm{T}=\mathrm{Tc}$ & 1.556 \\
\hline EBF-05 & 1.832 & 1.163 & 1.628 & $\mathrm{Tc}>$ Cu.Ta & $\mathrm{T}=\mathrm{Cu} . \mathrm{Ta}$ & 1.628 \\
\hline
\end{tabular}

Overall, it appears that the lowest fundamental period of structure is in the EBF-02 model, which indicates that the structure with the bracing configuration has a shorter cycle time period than the other models, while the MRF model has a longer cycle time period. The all of EBF model has higher stiffness compared to the MRF model.

\subsection{Lateral Deformation and Drift}

The results of lateral deformation and drifts story in the $\mathrm{X}$-axis and $\mathrm{Y}$-axis directions shown in Figure 6 and Figure 7 have fullfilled the requirements according to SNI 1726:2019. The lateral deformation and drift that occurs in the MRF model is greater than all of the EBF model, which 
indicates that the MRF model is more flexible than the EBF models. For the type of bracing configuration in the EBF system, the EBF-02 model has the lowest lateral deformation and drift values compared to other EBF models, which means that the model has more stiffness than other models.
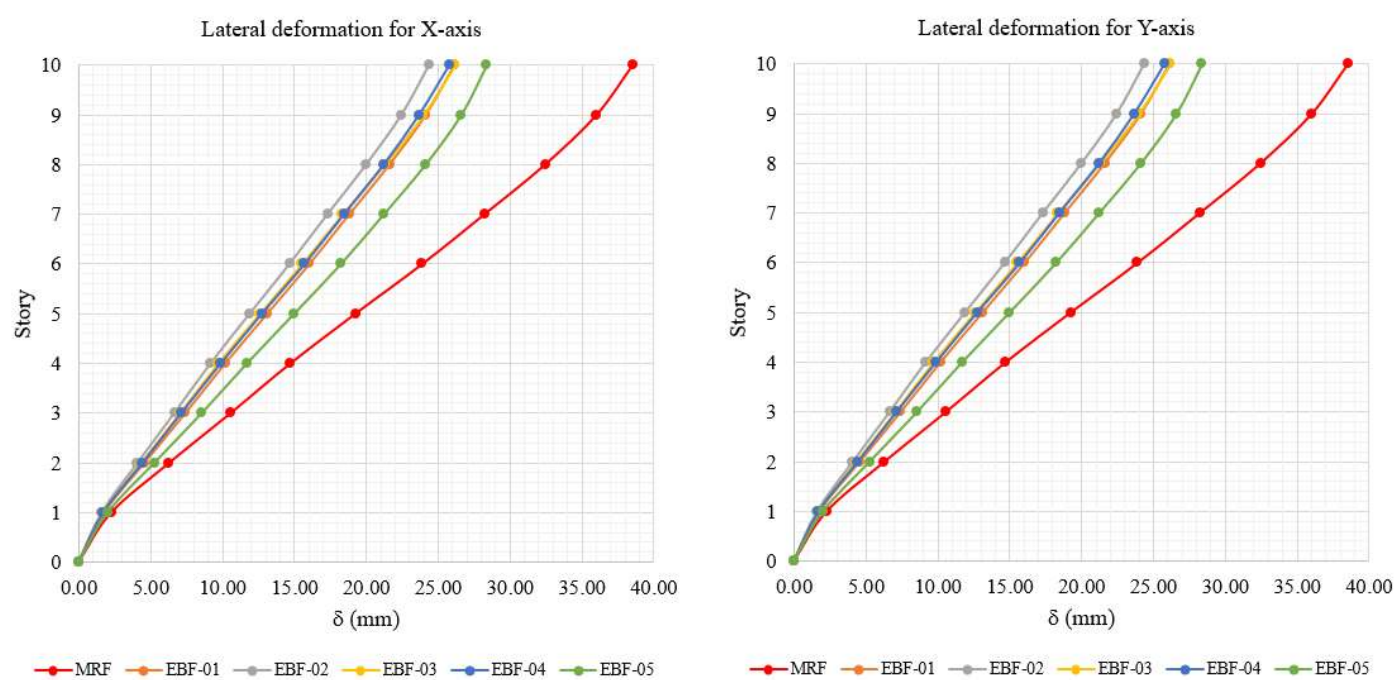

Figure 6. Lateral deformation for $\mathrm{X}$-axis and $\mathrm{Y}$-axis
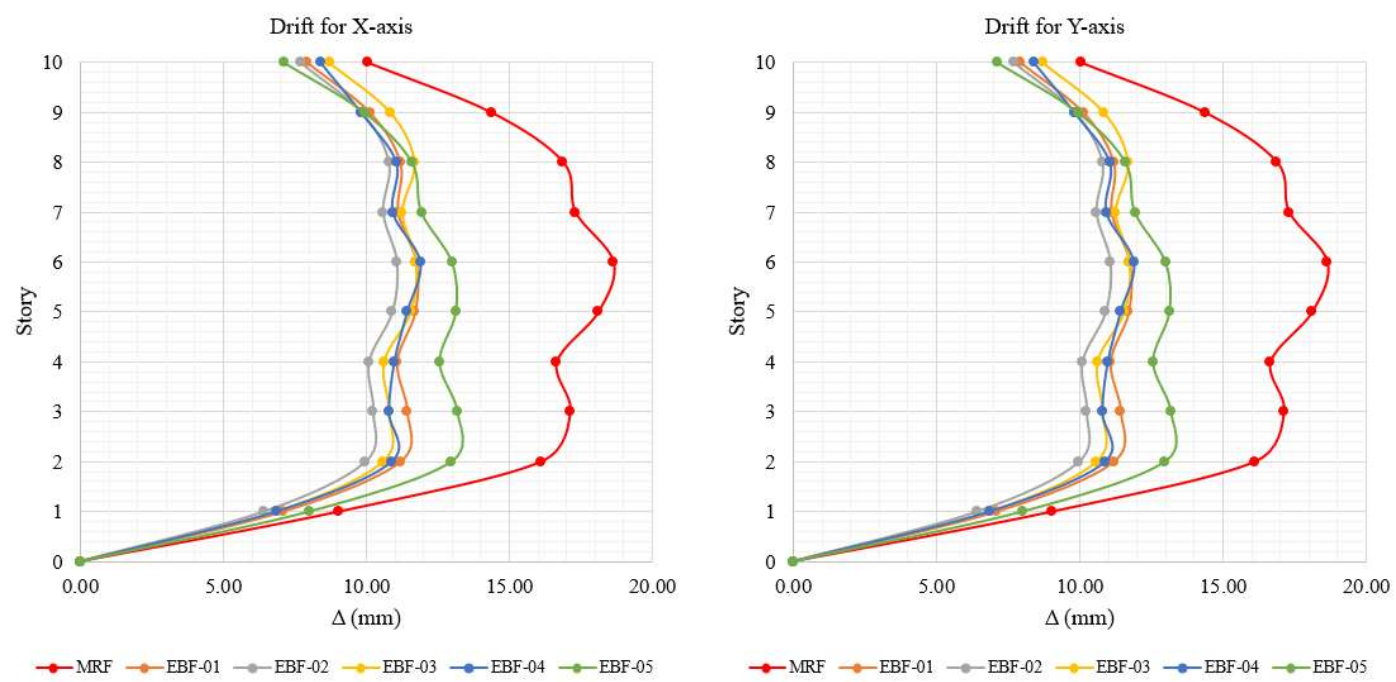

Figure 7. Drift for $\mathrm{X}$-axis and $\mathrm{Y}$-axis seismic direction

Table 4 and Table 5 explain that all structural models, both MRF model and EBF models, still fullfilled the limitation requirements for lateral deformation. The seismic load is still acceptable to the structure systems. Starting from the comparison of the EBF model to the MRF model, it can be seen that the EBF-02 model results in a reduction of $36.8 \%$ for the X-axis seismic direction and $36.6 \%$ for the $\mathrm{Y}$-axis seismic direction. The EBF-05 model achieved the small reduction with $26.4 \%$ for the $\mathrm{X}$-axis seismic direction and $23.3 \%$ for the $\mathrm{Y}$-axis seismic direction. 
Table 4. Displacement control for seismic load in X-axis

\begin{tabular}{|c|c|c|c|c|c|}
\hline Model & $\begin{array}{c}\text { Height } \\
\text { H } \\
\text { (m) }\end{array}$ & $\begin{array}{c}\text { Displacement } \\
\delta \\
(\mathrm{mm})\end{array}$ & $\begin{array}{l}\mathrm{H} / 240 \\
(\mathrm{~mm})\end{array}$ & $\begin{array}{c}\text { Control } \\
\delta<\mathrm{H} / 240\end{array}$ & $\begin{array}{c}\text { Deviation } \\
\text { to } \mathrm{MRF}\end{array}$ \\
\hline MRF & 40 & 38.55 & 166.67 & OK & \\
\hline EBF-01 & 40 & 26.13 & 166.67 & $\mathrm{OK}$ & $-32.2 \%$ \\
\hline EBF-02 & 40 & 24.38 & 166.67 & OK & $-36.8 \%$ \\
\hline EBF-03 & 40 & 26.16 & 166.67 & $\mathrm{OK}$ & $-32.2 \%$ \\
\hline EBF-04 & 40 & 25.77 & 166.67 & $\mathrm{OK}$ & $-33.2 \%$ \\
\hline EBF-05 & 40 & 28.37 & 166.67 & $\mathrm{OK}$ & $-26.4 \%$ \\
\hline
\end{tabular}

Table 5. Displacement control for seismic load in Y-axis

\begin{tabular}{cccccc}
\hline Model & $\begin{array}{c}\text { Height } \\
\mathrm{H}\end{array}$ & $\begin{array}{c}\text { Displacement } \\
\delta\end{array}$ & $\mathrm{H} / 240$ & Control & $\begin{array}{c}\text { Deviation } \\
\text { to MRF }\end{array}$ \\
& $(\mathrm{m})$ & $(\mathrm{mm})$ & $(\mathrm{mm})$ & $\delta<\mathrm{H} / 240$ & \\
\hline MRF & 40 & 38.58 & 166.67 & OK & \\
EBF-01 & 40 & 26.05 & 166.67 & OK & $-32.5 \%$ \\
EBF-02 & 40 & 24.45 & 166.67 & OK & $-36.6 \%$ \\
EBF-03 & 40 & 26.17 & 166.67 & OK & $-32.1 \%$ \\
EBF-04 & 40 & 25.81 & 166.67 & OK & $-33.1 \%$ \\
EBF-05 & 40 & 29.56 & 166.67 & OK & $-23.3 \%$ \\
\hline
\end{tabular}

\subsection{Base Shear}

From Figure 8 shown the shape of shear force in column and beam under seismic load for all of the model. The MRF model really has the shear force work in column and beam element, but for EBF model shear forces is dominant work in link beam element. This condition shows that the link beam in the EBF models has fucntioned properly.

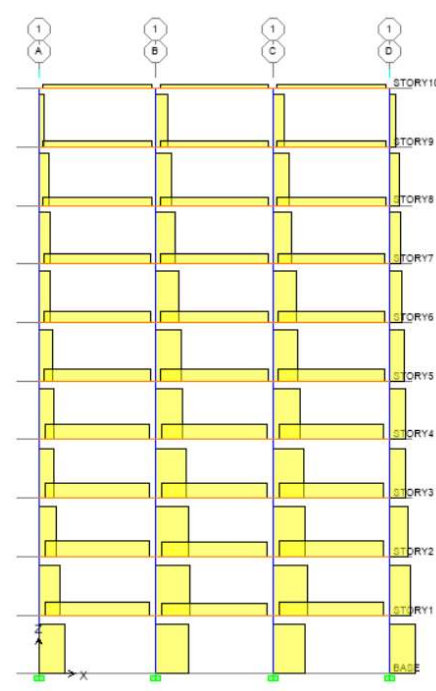

(a) MRF

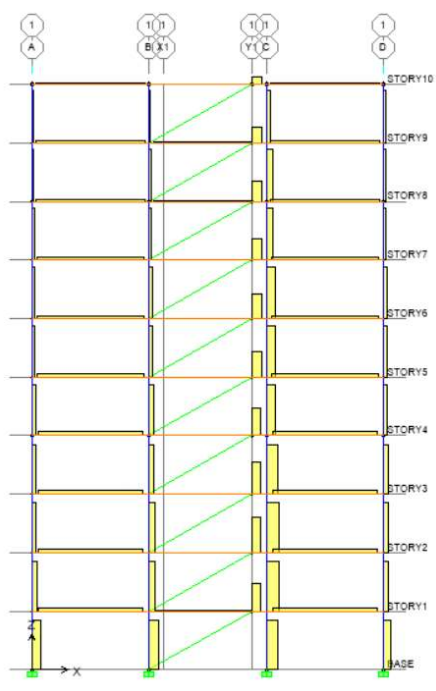

(b) EBF-01

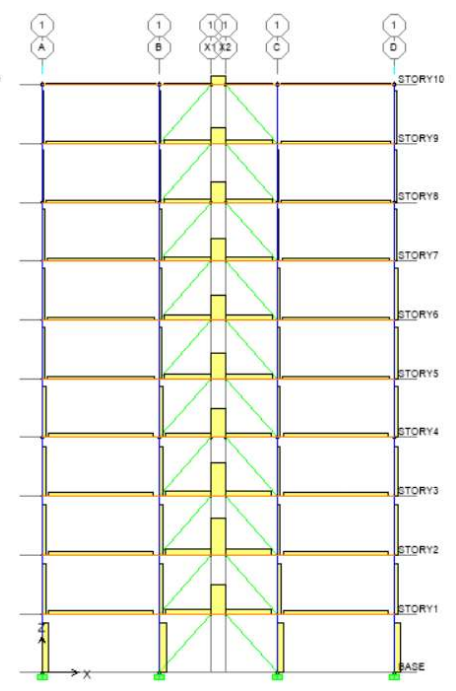

(c) EBF-02

Figure 8. Comparasion of shear force in column and beam for MRF and EBF in one axis seismic direction (part-1). 


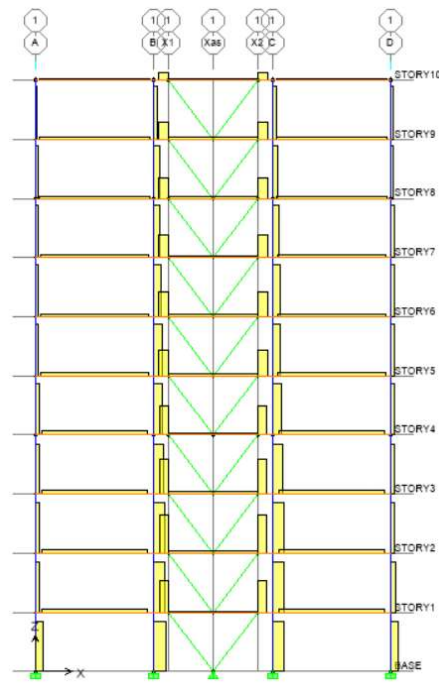

(d) EBF-04

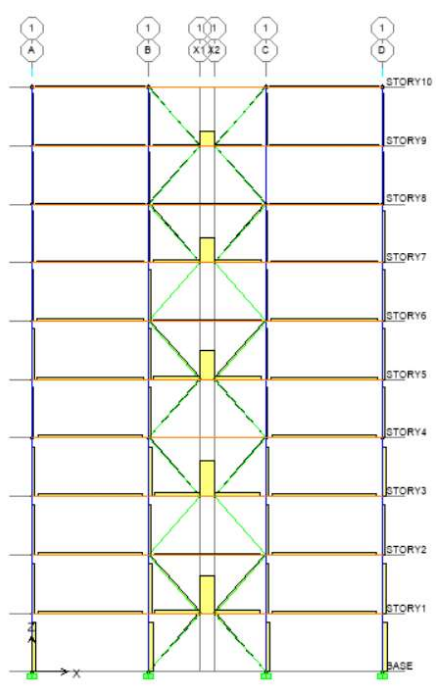

(e) EBF-05

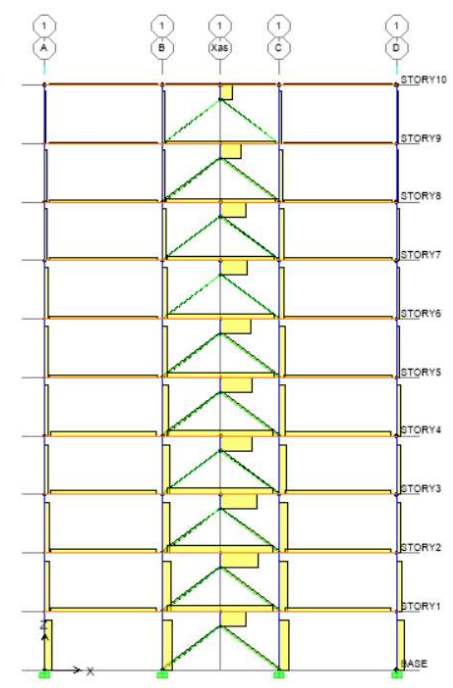

(f) EBF-06

Figure 8. Comparasion of shear forces in column and beam for MRF and EBF in one axis seismic direction (part-2).

In the provisions of SNI 1726: 2019 Article 7.9.1.4.1 requires that the base shear force resulting from the analysis of variance $\left(\mathrm{V}_{\mathrm{t}}\right)$ is not less than $100 \%$ of the shear force $(\mathrm{V})$ calculated through the equivalent static method. From the base shear force generated by each model in Table 6 , it shows that the EBF-02 model has the largest value of all the EBF models. For X-axis seismic direction has a magnitude $162,666.46 \mathrm{~kg}$ and $175,331.74 \mathrm{~kg}$ in the $\mathrm{Y}$-axis seismic direction. The lowest base shear is owned by the EBF-05 model, which a magnitude $145,431.96 \mathrm{~kg}$ for the X-axis seismic direction and $138,587.61 \mathrm{~kg}$ for the $\mathrm{Y}$-axis seismic direction.

Table 6. Control for base shear force

\begin{tabular}{cccccc}
\hline Model & & $\begin{array}{c}\mathrm{V}_{\mathrm{t}} \\
(\mathrm{Kg})\end{array}$ & $\begin{array}{c}\mathrm{V} \\
(\mathrm{Kg})\end{array}$ & $\begin{array}{c}\text { Control } \\
\left(\mathrm{V}_{\mathrm{t}}>\mathrm{V}\right)\end{array}$ & $\begin{array}{c}\text { Improvement } \\
\text { to MRF }\end{array}$ \\
\hline MRF & X-axis & $107,520.58$ & \multirow{2}{*}{$85,885.58$} & $\mathrm{OK}$ & \\
& Y-axis & $107,464.35$ & & $\mathrm{OK}$ & \\
EBF-01 & X-axis & $162,663.46$ & $87,015.52$ & $\mathrm{OK}$ & $51.3 \%$ \\
& Y-axis & $163,785.66$ & & $\mathrm{OK}$ & $52.4 \%$ \\
EBF-02 & X-axis & $175,713.60$ & \multirow{2}{*}{$87,375.42$} & $\mathrm{OK}$ & $63.4 \%$ \\
& Y-axis & $175,331.74$ & & $\mathrm{OK}$ & $63.2 \%$ \\
EBF-03 & X-axis & $167,537.22$ & \multirow{2}{*}{$87,287.10$} & $\mathrm{OK}$ & $55.8 \%$ \\
& Y-axis & $167,949.78$ & & $\mathrm{OK}$ & $56.3 \%$ \\
EBF-04 & X-axis & $167,264.78$ & \multirow{2}{*}{$87,375.42$} & $\mathrm{OK}$ & $55.6 \%$ \\
& Y-axis & $167,192.83$ & & $\mathrm{OK}$ & $55.6 \%$ \\
EBF-05 & X-axis & $145,431.96$ & \multirow{2}{*}{$87,427.25$} & $\mathrm{OK}$ & $35.3 \%$ \\
& Y-axis & $138,587.61$ & & $\mathrm{OK}$ & $29.0 \%$ \\
\hline
\end{tabular}

Both the MRF model and EBF models with all type of bracing configurations have fullfilled the requirements according to SNI 1726:2019 viewed from the result of base shear. The main difference is the shear force acceptable to the EBF system is greater than the MRF system. The EBF-02 model has the largest increase in base shear, reaching $63.4 \%$ for the $\mathrm{X}$-axis seismic direction and $63.2 \%$ for 
the Y-axis seismic direction. For the EBF-01, EBF-03 and EBF-04 models, both for the X-axis and $\mathrm{Y}$-axis seismic directions, an increase in base shear ranges between $50 \%-60 \%$. The lowest increase is owned by the EBF-05 model, reaching $35.3 \%$ for the $\mathrm{X}$-axis seismic direction and $29.0 \%$ for the Y-axis seismic direction.

\section{Conclusions}

The bracing configuration of EBF system can improve the structure response due to lateral seismic loads both in the parameters of the structure fundamental period, lateral deformation, drift and base shear. The Result of the analysis for all of bracing configuration are shown that model of EBF-02 model (Split K-Braces) has the biggest response value when compared to the MRF system. The parameter of lateral deformation for EBF-02 model that occurs deformation reduction reaching $36.8 \%$ in the $\mathrm{X}$-axis dan $36.6 \%$ in the $\mathrm{Y}$-axis seismic direction. The base shear forces in the $\mathrm{X}$-axis and $\mathrm{Y}$-axis respectively for EBF-02 model inreased by $63.4 \%$ dan $63.2 \%$. The lowest value for the parameter is owned by EBF- 05 model, namely Inverted Y-Braces, although overall it is still larger than the MRF system. The bracing configuration greatly affects the response of EBF system because of the behavior that occurs in the link beam, so that the selection for type of bracing configuration is also important in the EBF system structure design.

\section{Acknowledgements}

Thank you to Mrs. Shannen Hana Natalia Desriani for the article correction.

\section{References}

[1] Mohammadi, R.K. and Sharghi, A.H., "On the optimum performance-based design of eccentrically braced frames”, Steel Compos. Struct., Int. J., 16(5), 357-374, 2014.

[2] Lian, M., Su, M. and Guo, Y., "Seismic performance of eccentrically braced frames with high strength steel combination", Steel Compos. Struct., Int. J., 18(6), 1517-1539, 2015.

[3] Qi, Y., Li, W. and Feng, N., "Seismic collapse probability of eccentrically braced steel frames", Steel Compos. Struct., Int. J., 24(1), 37-52, 2017.

[4] Daneshmand, Ardeshir, dan Behrokh H. Hashemi, "Performance of Intermediate and Long Links in Eccentrically Braced Frames". Journal of Cons. Steel Research, 70 (11) : 167-176, 2011.

[5] ANSI/AISC, 341-10, "Seismic Provisions for Structural Steel Buildings". American Institute of Steel Construction, Chicago, Illinois, 2010.

[6] Popov. Egor P., Kazuhiko Kasai, dan Michael D. Engelhardt, "Advances in Design of Eccentrically Braced Frames". Buletin of the New Zealand National Society for Earthquake Engineering, Vol. 20, No. 1, March, 1987.

[7] Bruneau, Michel, Chia-Ming Uang, dan Rafael Sabbelli, "Ductile Design of Steel Structures - Second Edition”. McGraw-Hill Companies, Inc., United States of America, 2011.

[8] Richards, Paul W., dan Chia-Ming Uang, "Effect of Flange Width-Thickness Ratio on Eccentrically Braced Frames Link Cyclic Rotation Capacity". Journal of Struct. Eng., 131 (10): 1546-1552, 2005.

[9] Musmar, M.A., "Effect of Link on Eccentrically Braced Frames". Journal of Eng. Scie., Assiut Universiy. Vol 40, 1 (1): 35-43, 2012.

[10] Hashemi, Seyed H., "Ductility and Ultimate Strength of Eccentric Braced Frame". Proceeding of International Conference on Advanced Materials Engineering, Kairo, Egypt, 1-3 October, 2011.

[11] Rafael, Jusuf W.M. and Suswanto B, "Studi Perilaku Link Pendek, Link Menengah dan Link Panjang Pada Struktur Baja Sistem EBF”, ITS Journal of Civil Engineering, Vol. 32, No. 1, May, 2017.

[12] SNI 1729:2015, "Spesifikasi untuk Bangunan Gedung Baja Struktural”, Badan Standardisasi 
Nasional, Jakarta, 2015.

[13] SNI 1726:2019, "Tata Cara Perencanaan Ketahanan Gempa untuk Struktur Bangunan Gedung dan Nongedung", Badan Standardisasi Nasional, 2019. 